\title{
Proximate analysis and in-vitro gas production of predominant forages in Afe Babalola University rangeland as feed resources for ruminant production
}

\author{
F. O. Bamigboye, O. Oluwarinde
}

Department of Agricultural Sciences, Afe Babalola University, Ado-Ekiti Nigeria

\begin{abstract}
In Nigeria, the major feed resource for ruminant production is the natural grazeland. However, most forage found on such lands cannot absolutely support ruminant production. Therefore, there is need to ascertain the nutritive values of predominant forages in Afe Babalola University before setting up a ruminant farm. Wet season forages: grasses, legumes, forbes and tresses were sampled and analysed for proximate composition and in-vitro gas production using standard techniques. It was found that crude protein ranged between 12.2 and $27.3 \%$ in Terminalia catappa and Leucaena leucocephala respectively. The ash content varied from $6.0-22.0 \%$ in Andropogon gayanus and Asclepias syriaca respectively. Crude fibre of the forages was between 12.5 and $28.0 \%$ in L. leucocephala and Centrosema pubescens respectively. Gas production was measured for $24 \mathrm{hrs}$ at $3 \mathrm{hr}$ intervals. At mid-fermentation, gas production ranged between 4.0 and $13.3 \mathrm{ml} / 200 \mathrm{mgDM}$ (T. catappa and A. syriaca respectively). While at termination, it was from 9.0 - 22.67ml/200mgDM in $T$. catappa and $A$. syriaca respectively. Significant differences $(P<0.05)$ existed among tested forages. Organic matter digestibility was from 37.7-58.54\% in Tridax procumbens and A. syriaca respectively. Short chain fatty acid ranged from 0.27 - 0.6 $\mu$ mol in T. catappa and A. syriaca respectively. The methane gas ranged from 3.33$5.67 \mathrm{mmol}$ in Terminalia catappa and Calopogonium mucunoides respectively. In conclusion, most of the forages were found to be adequate for ruminant production in crude protein component. They were all noted to be very low in methane gas production which connotes energy loss in ruminant production. A good mixture of examined forages therefore, might serve as adequate feed resources for ruminant production in the area.
\end{abstract}

Keywords- Forages, methane gas, crude protein, ruminants, native grassland.

\section{INTRODUCTION}

Low productivity of ruminant livestock is mainly hinged on poor quality forage and its unavailability in quantity. The major resources for ruminants are cereal crop residues and pastures from rangelands. Livestock graze on about $26 \%$ of the world's land area. Tchinda et al. (1993) reported that native pastures are the most widely available low cost feeds for ruminants in the tropics. Native rangelands offer the cheapest source of nutrients for the ruminants. It is however an accepted fact that for a greater part of the year, grasslands in the tropics do not supply sufficient nutrients to stocks for actualizing enhanced productivity. Forage digestibility is related to intake rate, and affects animal performance positively. In addition, leafy swards provide more suitable intake conditions in view of the characteristics of animal ingestive behavior (Benvenutti et al., 2008).

In Nigeria, ruminants slowly gain weight in the rainy season and rapidly loose it in the dry season, yet in the traditional animal husbandry, ruminants are mainly fed with grasses, so that improved livestock production is not likely attainable and sustainable by forage grasses alone (Babayemi and Bamikole, 2006). Babayemi et al., (2003) had earlier reported that the forages are unimproved and low in nutritive values during the wet season, while during the dry season proper, they are fibrous, lignified with low protein values and even in short supply. Lamidi et al. (2010) agreed with this by reporting that available forages for most part of the year are low in protein content which leads to marked decrease in voluntary intake and digestibility, and subsequently leads to substantial weight loss of the animals during this period. The success of the livestock industry anywhere in the world depends greatly on feed quantity and quality. However, the expensive nature of conventional feed as a result of competition between man 
and livestock (Ogunbosoye and Babayemi, 2010), makes this combination difficult. Afe Babalola University, AdoEkiti has a very large expanse of rangeland which might be suitable as feed resource for ruminant production. However, the nutritive value of predominant forages in the area is yet to be determined and documented.

\section{MATERIALS AND METHOD}

\section{Description of the study area}

Afe Babalola University is located in Ado Ekiti, Nigeria. Ado Ekiti is a city in southwest Nigeria, the state capital and headquarters of the Ekiti State. It is also known as Ado. The people of Ado Ekiti are mainly of the Ekiti sub-ethnic group of the Yoruba (Wikipedia, 2016). Ado-Ekiti is mainly an upland zone, rising over 250meters above sea level. Ekiti State lies between longitude 5 $5^{\circ} 13^{\prime} 17$ East of Greenwich meridian and latitude 70 37'16 North of the Equator. The weather condition of the study area is tropical climate with temperature $26^{\circ} \mathrm{C}$, humidity $74 \%$, Rainfall $300-1100 \mathrm{~mm}$.

\section{Sample collection for analysis}

Predominant forages were collected at Afe Babalola University Ado Ekiti. Common forages (trees, legumes, Forbs and grasses) in the study area were collected in the wet season (June peak of rainy season). Two forages per type were harvested for the analysis (tree: Terminalia catappa and Leucaena leucocephala, legumes: Centrosema pubescens and Calopogonium mucunoides, forbs: Tridax procumbens and Asclepias syriaca, grasses: Panicum maximum and Andropogon gayanus). The fresh samples were weighed and air dried for 48 hours and oven dried to a constant weight at $105^{\circ} \mathrm{C}$. Oven dried samples were milled (2mm sieve) and kept for analysis.

\section{Proximate analysis}

Crude protein, crude fiber, ether extract and ash contents of forages were determined according to AOAC (2000). Kjeldahl procedure was used to determine the total nitrogen present in forage samples. It was effected through the breaking down of $2 \mathrm{~g}$ sample in $25 \mathrm{ml}$ concentrated $\mathrm{H}_{2} \mathrm{SO}_{4}$ acid plus selenium, using Gerhardt Kjeldahtherm until an opaque colour was obtained. The digested sample was rested for 12 hours, diluted with distilled water and made up to the mark in a 250 volumetric flask. $5 \mathrm{ml}$ of digest was pipette and distilled with $40 \% \mathrm{NaOH}$ solution and the ionized ammonium was trapped by boric acid. The distillate was immediately titrated $(\mathrm{n}=3)$ with $0.01 \mathrm{~N}$ hydrogen chloride. The crude protein was obtained by multiplying the nitrogen with factor: 6.25 .

\section{In-vitro}

fermentation

procedures

Preparation of the buffer and rumen liquor was carried out as described by Menke and Steingass (1988). The substrate was placed in calibrated gas tight plastic syringes fitted with a piston. The syringes were put in an incubator at $39 \pm 1^{\circ} \mathrm{C}$. Rumen liquor was collected from three female West African Dwarf (WAD) goats, sieved with a four layered cheese cloth and mixed with a sodium buffer $\left(9.8 \mathrm{~g} \mathrm{NaHCO}_{3}\right.$ $+2.77 \mathrm{~g}(\mathrm{Na}) 2 \mathrm{HPO}_{4}+0.57 \mathrm{~g} \mathrm{KCl}+0.47 \mathrm{gNaCl}+$ $0.12 \mathrm{gMgSO}_{4} 7 \mathrm{H}_{2} \mathrm{O}+\mathrm{CaCl}_{2} . \mathrm{H}_{2} \mathrm{O}$ per $1000 \mathrm{ml}$ ) in a ratio1:2 $\mathrm{v} / \mathrm{v}$. $200 \mathrm{mg} \mathrm{DM}$ of each sample with $30 \mathrm{ml}$ of rumen liquor and buffer were placed in each syringe and incubated in triplicate under continuous flushing with $\mathrm{CO}_{2}$. A blank (rumen liquor + buffer) without substrate was incubated at the same time. The reading of the blank was subtracted from that of the other syringes. Gas production was recorded at 3, 6, 9, 12, 15, 18, 21 and 24h. After 24h of incubation, $4 \mathrm{ml}$ of $\mathrm{NaOH}(10 \mathrm{M})$ was introduced into inoculums as reported by Fievez et al. (2005) to estimate the amount of methane produced. The value of gas produced at intervals was plotted against the using the equation $\mathrm{Y}=\mathrm{a}+\mathrm{b}$ (1-ect) (Ørskov and Mc Donald, 1979), where $\mathrm{Y}=$ volume of gas produced at time $\mathrm{t}, \mathrm{a}=$ initial gas produced, $\mathrm{b}=$ gas produced from insoluble but degradable fraction, $\mathrm{c}=$ the rate constant for the degradation of ' $\mathrm{b}$ ' and $\mathrm{t}=$ incubation time.

\section{Statistical Analysis}

Data collected were subjected to analysis of variance at $\mathrm{p}=0.05$.

\section{RESULTS AND DISCUSSION}

Proximate composition of predominant forages in Afe Babalola University rangeland

Shown in Table 1 is the proximate composition of predominant forages in Afe Babalola University. The crude protein for the present study varied from $12.2-27.3 \%$ in $T$. catappa and L. leucocephala respectively. The ash content also varied from $6-22 \%$ in A. gayanus and A. syriaca respectively. Crude fibre of the forages was between 12.5 and $28.0 \%$ in $L$. leucocephala and $C$. pubescens respectively. The ether extract ranged from $2.0-9.5 \%$ ( $A$. gayanus and T. catappa respectively), while the Nitrogen free extract of the forages was observed to vary from 30.5 $53.7 \%$ in A. syriaca and A. gayanus respectively. It was noted that there were significant differences $(\mathrm{P}<0.05)$ in all the measured parameters among the forages. 
Table.1: Proximate composition (\% DM) of predominant forages in Afe Babalola University

\begin{tabular}{llllll}
\hline Forages & Ash & CP & CF & EE & NFE \\
\hline C. pubescens & $7.0^{\mathrm{g}}$ & $18.7^{\mathrm{d}}$ & $27.0^{\mathrm{c}}$ & $7.0^{\mathrm{b}}$ & $40.3^{\mathrm{c}}$ \\
T. catappa & $14.0^{\mathrm{d}}$ & $12.2^{\mathrm{f}}$ & $17.7^{\mathrm{e}}$ & $9.5^{\mathrm{a}}$ & $46.6^{\mathrm{b}}$ \\
C. mucunoides & $10.0^{\mathrm{e}}$ & $23.8^{\mathrm{b}}$ & $28.0^{\mathrm{b}}$ & $8.0^{\mathrm{b}}$ & $30.2^{\mathrm{e}}$ \\
A. gayanus & $6.0^{\mathrm{h}}$ & $13.7^{\mathrm{e}}$ & $24.6^{\mathrm{d}}$ & $2.0^{\mathrm{f}}$ & $53.7^{\mathrm{a}}$ \\
T. procumbens & $20.0^{\mathrm{b}}$ & $18.9^{\mathrm{d}}$ & $18.5^{\mathrm{e}}$ & $7.5^{\mathrm{b}}$ & $35.1^{\mathrm{d}}$ \\
L. leucocephala & $16.0^{\mathrm{c}}$ & $27.3^{\mathrm{a}}$ & $12.5^{\mathrm{f}}$ & $8.0^{\mathrm{b}}$ & $36.2^{\mathrm{d}}$ \\
P. maximum & $8.0^{\mathrm{f}}$ & $13.6^{\mathrm{e}}$ & $31.9^{\mathrm{a}}$ & $4.5^{\mathrm{e}}$ & $42.0^{\mathrm{c}}$ \\
A. syriaca & $22.0^{\mathrm{a}}$ & $20.4^{\mathrm{c}}$ & $18.1^{\mathrm{e}}$ & $9.0^{\mathrm{a}}$ & $30.0^{\mathrm{e}}$ \\
S.E.M & 0.88 & 1.24 & 1.0 & 0.045 & 1.58 \\
\hline
\end{tabular}

a,b,c,de,, $\mathrm{f}=$ Means on the same column with similar superscript letters are not significantly different $(\mathrm{P}<0.05)$.

Where, $\mathrm{CP}=$ Crude protein, $\mathrm{CF}=$ Crude fibre, $\mathrm{EE}=$ Ether extract, NFE $=$ Nitrogen free extract. $\mathrm{SEM}=$ Standard error of means

Proximate composition is usually the basic and most common form of forages evaluation by animal nutritionist. There are many factors affecting proximate composition and mineral content of forages such as stage of growth maturity, species or variety (Agbagla-Dohnani et al., 2001; Promkot and Wanapat, 2004). The Crude protein (CP) content of Asclepias syriaca, Calopogonium mucunoides and $L$. leucocephala were higher than the other species. The $\mathrm{CP}$ of the forage species ranged from 12.2 to $27.3 \%$, which is above the $7 \% \mathrm{CP}$ requirement for ruminants which will provide ammonia required by rumen microorganisms to support optimum microbial activity. Andropogom gayanus had a higher CP of $13.7 \%$ compared to Odedire and Babayemi (2008) CP: $9.36 \%$ the ether extract and ash had lower values to that reported by the same authors. The ash content (8\%) of Panicum maximum noted in this study was different and lower to the findings of Odedire and Babayemi (2008) however, the CP (13.6) was higher than that reported by the same authors.

Amata and Lebari, (2011) reported crude protein of $11.70 \%$ in Terminalia catappa as against $12.2 \%$ noted in the present study. The workers however reported lower level of crude fibre and ash than reported in the present study. The values obtained for proximate composition of Calopogonium mисиnoides were lower in terms of crude protein: $23.8 \%$ and Nitrogen free extract: $30.2 \%$ but higher in ash: $9.80 \%$, crude fibre: $28.0 \%$ and ether extract: $8.0 \%$ compared to what Mecha and Adegbola (1980) reported; ash (9.80\%), crude fibre $(21.60 \%)$, ether extract $(3.10 \%)$ crude protein $(24.08)$ and Nitrogen free extract (41.42).
The nutrient composition of Centrosema pubescens as obtained in this present study differs from that of Nworgu and Egbunike, 2013 who obtained 9.14\% (ash) which is considered higher than the present study ash: $7.0 \%$, crude protein $23.4 \%$ was also found higher than crude protein $18.7 \%$ of the present study. However, lower values for crude fibre: 8.80 and ether extract: $3.32 \%$ compared to that of the present study: crude fibre: $17.7 \%$ and ether extract: 9.5\% were observed.

Generally, the variation that existed between the present study and the past works on the forages considered may be traced to time and seasons of harvest, age of plant, leaf to petiole ratio, ecological location and edaphic (soil) (Makkar and Beacker, 1997; Babayemi and Bamikole, 2006).

In-vitro gas production of forages collected from the rangeland in Afe Babalola University.

Presented in Figure 1 is the in-vitro gas production of forages from the rangeland in Afe Babalola University. At the onset of fermentation, gas production ranged from $0.00 \mathrm{ml} / 200 \mathrm{mg} \mathrm{DM}$ in C. mucunoides, $P$. maximum, $T$. procumbens, $C$. pubescens, A. gayanus and T. catappa to $2.33 \mathrm{ml} / 200 \mathrm{mg} \mathrm{DM}$ in L. leucocephala. However at mid fermentation, it ranged from $4.00 \mathrm{ml} / 200 \mathrm{mg} \mathrm{DM}$ ( $T$. catappa) to $13.33 \mathrm{ml} / 200 \mathrm{mg} \mathrm{DM}$ (A. syriaca), while at termination, the gas production ranged from $9.00 \mathrm{ml} / 200 \mathrm{mg}$ DM to $22.67 \mathrm{ml} / 200 \mathrm{mg}$ DM in $T$. catappa and A. syriaca respectively. Gas production varied significantly $(\mathrm{P}<0.05)$ in the forages from the $3^{\text {rd }}$ hour to termination at $24^{\text {th }}$ hour in the present study. 


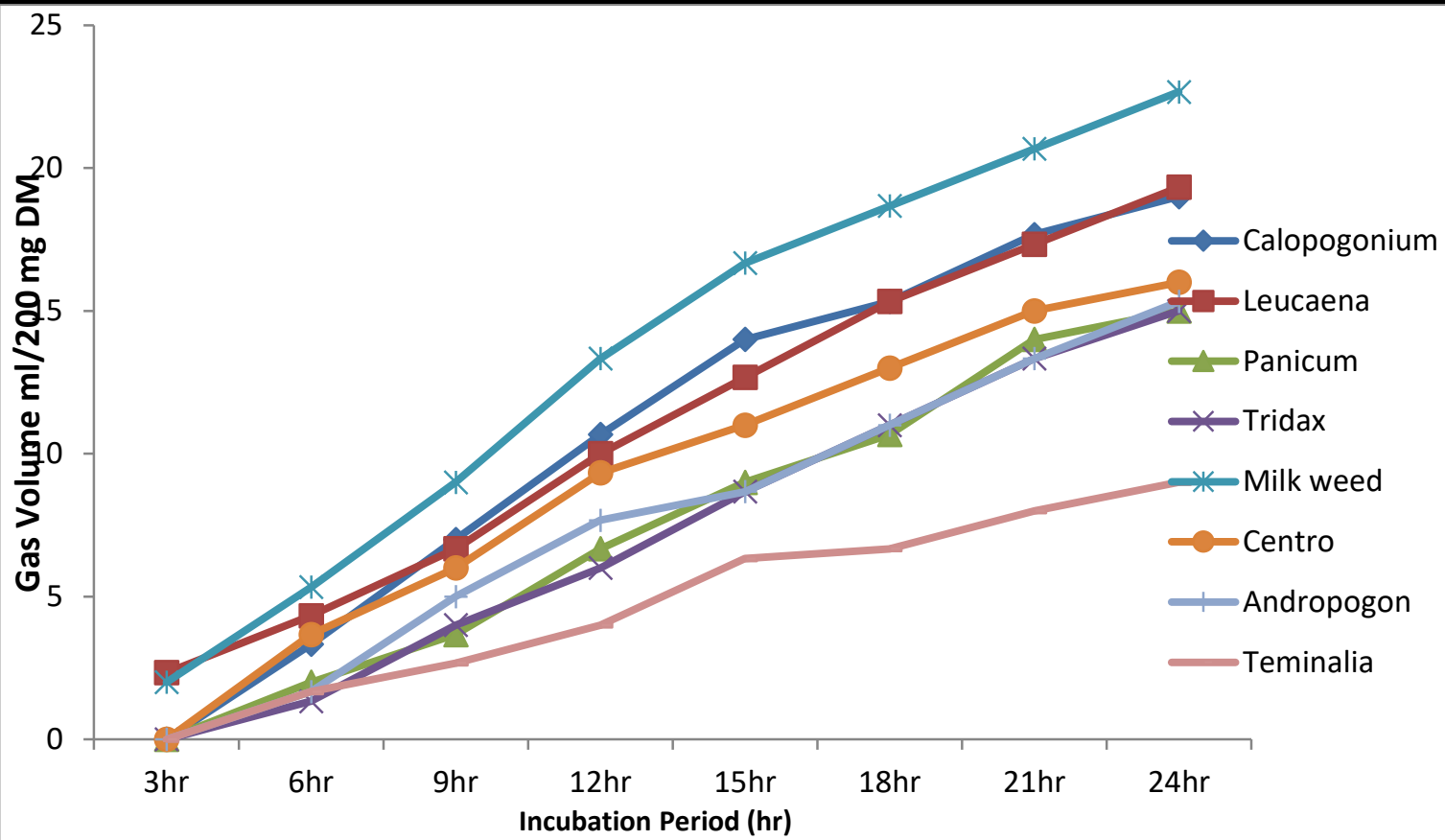

Fig.1:In vitro gas production of predominant forages in Afe Babalola University

Key

Terminalia catappa (Terminalia) Leucaena leucocephala (Leucaena), Centrosema pubescens (Centro), Calopogonium mucunoides (Calopogonium), Tridax procumbens (Tridax) Asclepias syriaca (milk weed), Panicum maximum (panicum) and Andropogon gayanus (Andropogon).

Presented in Table 2 is the Metabolisable energy $\mathrm{MJ} / \mathrm{Kg}$ DM, organic matter digestibility (\%) and short chain fatty acid $(\mu \mathrm{mol})$ of predominant forages in Afe Babalola
University. ME is an indication of energy and it ranged between 5.00 and $6.50 \mathrm{MJ} / \mathrm{Kg} \mathrm{DM}$ (Tridax procumbens and Asclepias syriaca respectively). It was found to be significantly different among forages. Organic matter digestibility ranged from $37.7-58.54 \%$ in Tridax procumbens and Asclepias syriaca respectively with significant difference among forages. Short chain fatty acid which is an indication of energy made available to the host animal ranged from 0.27-0.60 $\mu$ mol (Terminalia catappa and Asclepias syriaca respectively).

Table.2: Metabolisable energy (MJ/Kg DM), organic matter digestibility (\%) and short chain fatty acid ( $\mu$ mol)

\begin{tabular}{llll}
\multicolumn{4}{c}{ of predominant forages in Afe Babalola University } \\
\hline Forages & ME & OMD & SCFA \\
\hline C. pubescens & $5.51^{\mathrm{bc}}$ & $50.63^{\mathrm{b}}$ & $0.44^{\mathrm{bc}}$ \\
C. mucunoides & $5.92^{\mathrm{b}}$ & $44.72^{\mathrm{c}}$ & $0.52^{\mathrm{b}}$ \\
L. leucocephala & $5.57^{\mathrm{bc}}$ & $46.67^{\mathrm{c}}$ & $0.52^{\mathrm{b}}$ \\
A. syriaca & $6.50^{\mathrm{a}}$ & $58.54^{\mathrm{a}}$ & $060^{\mathrm{a}}$ \\
P. maximum & $5.68^{\mathrm{b}}$ & $45.44^{\mathrm{c}}$ & $0.42^{\mathrm{c}}$ \\
T. procumbens & $5.00^{\mathrm{d}}$ & $37.70^{\mathrm{d}}$ & $0.40^{\mathrm{c}}$ \\
A. gayanus & $5.15^{\mathrm{cd}}$ & $39.85^{\mathrm{d}}$ & $0.43^{\mathrm{c}}$ \\
T. catappa & $5.02^{\mathrm{d}}$ & $45.48^{\mathrm{c}}$ & $0.27^{\mathrm{d}}$ \\
SEM & 0.07 & 2.90 & 0.0021 \\
\hline
\end{tabular}

${ }^{\mathrm{a}, \mathrm{b}, \mathrm{c}}=\mathrm{M}$ eans on the same column with similar superscript letters are not significantly $\operatorname{different}(\mathrm{P}<0.05)$.

Where ME - Methabolisable energy, OMD - Organic matter digestibility, SCFA - Short chain fatty acid, SEM = Standard error of means 
Norton (2003) justifies the use of forages in small quantities in order to supplement poor quality pastures and crop residues. It has been suggested that the gas production technique is more reliable than the nylon bag method for determining nutritive value of feeds containing antinutritive factors (Khazaal et al., 1993). Nature and fibre levels, presence of anti-nutrition factor had been reported to influence the amount of gas produced during fermentation (Babayemi 2004). High level of crude fibre reduce digestibility which is synonymous to in-vitro gas production. In-vitro technique is a more reliable tool for evaluating ruminant forages. Though the two methods are independent of each other, they are interrelated (Babayemi et al., 2004; Fievez et al., 2005).

Gas production is associated with volatile fatty acid production following fermentation of substrate (Blummel and Ørskov 1993). In addition, the application of models permits the fermentation kinetics of the soluble and readily degradable fraction of the feeds, and more slowly degradable fraction to be described (Gatechew et al., 1998). Moreover the gas production parameters of trees might demonstrate differences in their nutritional value that may be closely related to their chemical composition (Cerrillo and Juarez 2004). The inconsistency observed in the gas production is as a result of the different rate of different anti nutritional content as well as the forage degradability. In-

Table.3: In-vitro gas production characteristic of predominant forages in Afe Babalola University rangeland

\begin{tabular}{lllllll}
\hline Forages & $\mathbf{a}$ & $\mathbf{a}+\mathbf{b}$ & $\mathbf{b}$ & $\mathbf{c}$ & $\mathbf{T}$ & $\mathbf{Y}$ \\
\hline C. pubescens & $3.67^{\mathrm{a}}$ & $16.00^{\mathrm{b}}$ & $12.33^{\mathrm{d}}$ & 0.051 & $12.00^{\mathrm{ab}}$ & $9.33^{\mathrm{ab}}$ \\
C. mucunoides & $3.33^{\mathrm{ab}}$ & $19.00^{\mathrm{b}}$ & $15.67^{\mathrm{bc}}$ & 0.059 & $12.00^{\mathrm{ab}}$ & $11.00^{\mathrm{a}}$ \\
L. leucocephala & $2.33^{\mathrm{ab}}$ & $19.00^{\mathrm{b}}$ & $17.00^{\mathrm{b}}$ & 0.052 & $13.00^{\mathrm{ab}}$ & $11.33^{\mathrm{a}}$ \\
A. syriaca & $2.00^{\mathrm{ab}}$ & $22.67^{\mathrm{a}}$ & $20.67^{\mathrm{a}}$ & 0.043 & $9.00^{\mathrm{b}}$ & $9.67^{\mathrm{ab}}$ \\
P. maximum & $2.00^{\mathrm{ab}}$ & $15.00^{\mathrm{c}}$ & $13.00^{\mathrm{cd}}$ & 0.041 & $12.00^{\mathrm{ab}}$ & $7.33^{\mathrm{ab}}$ \\
T. procumbens & $1.67^{\mathrm{b}}$ & $14.33^{\mathrm{c}}$ & $12.33^{\mathrm{d}}$ & 0.037 & $11.00^{\mathrm{ab}}$ & $6.33^{\mathrm{b}}$ \\
A. gayanus & $1.67^{\mathrm{b}}$ & $15.33^{\mathrm{c}}$ & $13.67^{\mathrm{cd}}$ & 0.032 & $10.00^{\mathrm{b}}$ & $6.00^{\mathrm{b}}$ \\
T. catappa & $1.67^{\mathrm{b}}$ & $9.00^{\mathrm{d}}$ & $7.33^{\mathrm{e}}$ & 0.054 & $14.00 \mathrm{a}$ & $5.67^{\mathrm{b}}$ \\
SEM & 0.96 & 3.67 & 3.00 & 0.0022 & 4.88 & 4.88 \\
\hline
\end{tabular}

$\mathrm{a}, \mathrm{b}, \mathrm{c}, \mathrm{d}=$ Means on the same column with similar subscript letters are not significantly $\operatorname{different}(\mathrm{P}<0.05)$.

a- initial gas produced/intercept, b- insoluble but degradable fraction, $a+b$ - potential extent of gas production, c-rate at which gas is produced, $\mathrm{Y}$ - gas volume, $\mathrm{SEM}=$ Standard error of means.

The intake of a feed is mostly explained by the rate of gas production (c) which affects the passage rate of feed through the rumen, whereas the potential gas production ( $a$ $+b$ ), is associated with degradability of feed (Khazaal et al., 1995). Therefore the higher values obtained for the potential gas production in the Calopogonium mucunoides, Leucaena leucocephala and Asclepias spp might indicate a better nutrient availability for rumen microorganisms. vitro estimations of feed degradation are important tools for ruminant nutritionists. These methods measure either substrate disappearance or fermentation products (Blümmel et al 1997). In the present study, forages with high CP produced higher gas volume. Digestibility has been reported to be synonymous to in vitro gas production (Fievez et al., 2005 ) that is, forages with high gas production will exhibit better digestibility.

In-vitro gas production characteristics of predominant forages in Afe Babalola University rangeland

Presented in Table 3 is the in-vitro gas production characteristic of predominant forages in Afe Babalola University. It was observed that ' $a$ ' which is the initial gas produced ranged between 1.67 and $3.67 \mathrm{ml}$ in $T$. procumbens, A. gayanus, T. catappa and $C$. pubescens respectively. Significant differences existed among the considered forages $(\mathrm{P}<0.05)$. The potential gas production from insoluble but degradable fraction ' $b$ ' varied from 7.33$20.65 \mathrm{ml} \mathrm{T}$. catappa and Asclepias syriaca respectively, while the rate of potential gas production $(\mathrm{a}+\mathrm{b})$ ranged from 9.00-22.67 $\mathrm{ml}$ in $T$. catappa and Asclepias syriaca respectively. Rate at which gas is produced 'c' ranged from $0.032-0.059(\mathrm{ml} / \mathrm{h})$ in Andropogom gayanus and Calopogonium mucunoides respectively with no significant differences among the forages.
Methane gas (mmol) produced at $24 \mathrm{~h}$ of incubating predominant forages in Afe Babalola University

Presented in Figure 2 is the methane gas (mmol) produced from incubating predominant forages in Afe Babalola University. The methane gas ranged from 3.33-5.67 mmol in Terminalia catappa and Calopogonium mucunoides respectively. 


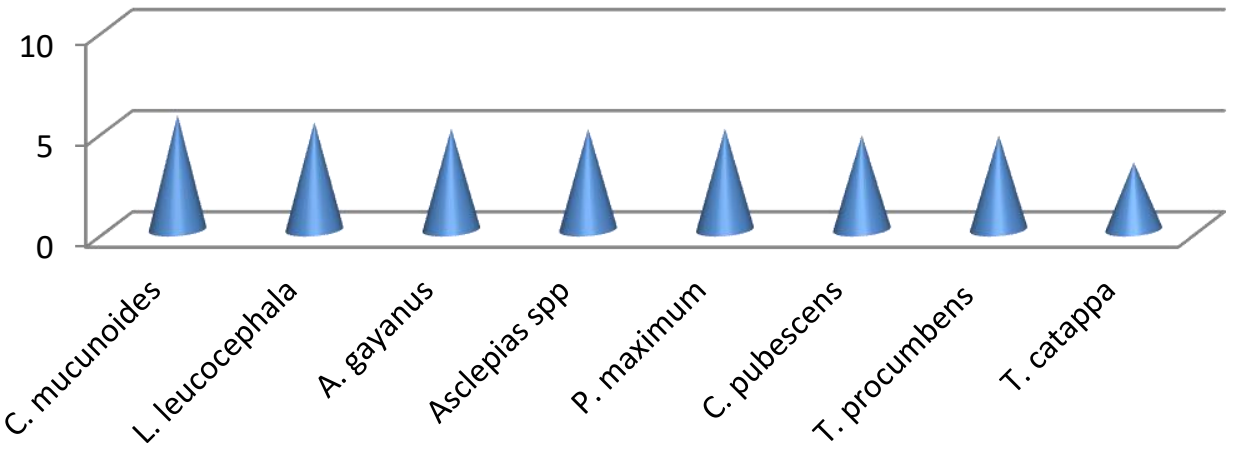

Fig.2: Methane gas (mmol) produced at 24 h of incubating forages

Methane production represent a significant energy loss to ruminants; it also contributes to global warming which is a worrisome phenomenon in the recent time and many tropical feedstuff have been indicated to increase methanogenesis (Babayemi et al., 2004; Babayemi and Bamikole, 2006).

\section{CONCLUSION}

The results revealed that In-vitro gas production techniques can be used to assess the nutritive value of forages. It unveiled the fact that most of the forages seem to be adequate in crude protein but deficient in ash content and fibre. Methane gas production was generally low and this is an indication that energy loss will be reduced and the forages will be environmentally friendly when fed to ruminants.

\section{REFERENCES}

[1] Agbagla-Dohnani, A., P. Noziere, G. Clement and M. Doreau, (2001). In sacco degradability chemical and morphological composition of 15 varieties of European rice straw. Anim. Feed Sci. Technol., 94: 15-27.

[2] AOAC (2000). Official Methods of Analysis, 21th edn. (Association of Official Analytical Chemist, Airlington, VA).

[3] Babayemi OJ, Bamikole MA (2004). Feeding goats with Guinea grass - Verano stylo and nitrogen fertilizer grass with energy concentrate. Arch. Zootec. $53: 13-23$.

[4] Babayemi, O.J, Bamikole, MA (2006). Effect of Tephrosia candida DC leaf and its mixtures with
Guinea grass on In-vitro fermentation changes as feed for ruminants in Nigeria. Pakistan J. Nutr.,5(1): 14-18

[5] Babayemi, O.J., Bamikole, M.A and Odunguwa B.O. (2003). Haematological and Biochemical components of West African dwarf goats fed Tephrosia bracteolata - based forage. Trop. Anim. Prod. Invest. 6:31-38.

[6] Benvenutti, M.A.; Gordon, I.J.; Poppi, D.P.; Crowther, R.; Spinks, W. 2008. Foraging mechanics and their outcomes for cattle grazing reproductive tropical swards. Applied Animal Behaviour Science 113:1531.

[7] Blümmel M, Makkar H P S and Becker K (1997) Invitro gas production: a technique revisited. Journal of Animal Physiology and Animal Nutrition, 77:24-34

[8] Blummel, M. and E.R. Ørskov, (1993). Comparison of In-vitro gas production and nylon bag degradability of roughages in predicting feed intake in cattle. Anim. Feed Sci. Technol., 40: 109-119.

[9] Cerrillo M A and Juarez R A S (2004). In-vitro gas production parameters in cacti and tree species commonly consumed by grazing goats in a semiarid region of North Mexico. Livestock Research for Rural Development. $\quad 16 \quad$ (4) 2004, http://www.cipav.org.co//rrd/lrrd16/4/cerr16021.htm

[10] Fievez, V., O.J. Babayemi and D. Demeyer, (2005) Estimation of direct and indirect gas production in syringes: a tool to estimate short chain fatty acid

[11] Getachew G, Blümmel M, Makkar H P S and Becker $\mathrm{K}$ (1998) In-vitro gas measuring techniques for assessment of nutritional quality of feeds: A review. Animal Feed Science and Technology, 72:261-281. 
[12] Khazaal K A, Dentinho M T, Ribeiro R and Ørskov E R (1993). A comparison of gas production during incubation with rumen contents In-vitro and nylon bag degradability as predictors of the Apparent digestibility in vivo and voluntary intake of hays. Animal Production, 57: 105-112.

[13] Khazaal, K., M.T. Dentinho, J.M. Ribeiro and E.R. Ørskov, (1995). Prediction of apparent digestibility and voluntary feed intake of hays fed to sheep: Comparison between using fibre component, in-vitro digestibility or characteristics of gas production or nylon bag degradation. Anim. Sci., 61: 521-538

[14] Lamidi, A.A., Aina, A.B.J and Sowande, S.O. (2010). Nutrient digestibility and nitrogen balance in West African dwarf goats fed blended diets for dry season. Proc. 35th Conf. Nig. Soc. Anim. Prod. held 14th 17th March, 2010 at the Univ. of Ibadan, Nigeria. Pp. $499-501$.

[15] Mecha I. and T.A. Adegbola (1980). Department of Animal Science University of Nigeria Nsukka, Nigeria: Chemical composition of some southern Nigeria forage eaten by goats.

[16] Norton, B.W. (2003). The Nutritive value of tree legumes. http://www.fao.org/ag/AGPC/doc/Publicat/ Gutt-shel/x5556e0j.htm.pp.1-10

[17] Odedire, J. A. and O. J. Babayemi (2008): Comparative studies on yield and chemical composition of Panicum maximum and Andropogon gayanus as influenced by Tephrosia candida and Leucaena leucocephala. Livestock Research for Rural Development 20(2): 1-8.

[18] Ogunbosoye, D. O. and Babayemi, O. J. (2010). Voluntary intake of Non-legume fodders offered simultaneously to West African Dwarf goats for a period of six hours. Proc. 35th Conf. Nig. Soc. for Anim. Prod. 14 - 17th March, 2010, Univ. of Ibadan, Nigeria. Pp. $518-520$.

[19] Promkot, C. and M. Wanapat, (2004). Ruminal degradation and intestinal digestion of crude protein of tropical resources using nylon bag and three-step Invitro procedure in dairy Cattle. In: Proceedings of the Agricultural Seminar, Animal Science/Animal Husbandry. Held at Sofitel Raja Orchid Hotel 27-28 January 2004.

[20] Stabile, S.S.; Bodini, A.P.; Jank, L.; Renno, F.P.; Santos, M.V.; Silva, L.F.P. 2012. Expression of genes from the lignin synthesis pathway in guineagrass genotypes differing in cell-wall digestibility. Grass and Forage Science 67:43-54.
[21] Statistical Analysis System Institute Inc. (2000): SASSTAT programme, Cary, NC: SAS Institute Inc.

[22] Tchinda B, D Wegard and R M Njwe (1993): Rumen degradation of elephant grass supplemented with graded levels of perennial peanut by West African dwarf sheep. In: Lebbie S H B, Rey B and Irungu E K (Editors). Small Ruminant Research and Development in Africa. Proceedings of the second biennial conference of the African small ruminants research network AICC, Arusha, Tanzania, 7-11, December 1992. ILCA/CTA. ILCA. Addis Ababa, Ethiopia pp $187-190$

http://www.fao.org/Wairdocs/ILRI/x5472B/x5472b11. $\underline{\mathrm{htm}}$ 